\title{
Investigation of Live Attenuated Measles Virus Vaccine as Anti Tumor Agent
}

\author{
Farah E. Ismaee $^{* 1}$, Ahmed M. Al-Shammari** and Shahlaa M. Salih* \\ *Departments of Biotechnology, College of Science, Al-Nahrain University, Baghdad-Iraq. \\ ${ }^{* *}$ Center for Cancer and Medical Genetic Researches, Head of Experimental Therapy Department, \\ Baghdad-Iraq. \\ 1E-mail:- Fara7_3essa@yahoo.com.
}

\begin{abstract}
This study was carried out to evaluate the antitumor effect of live attenuated measles virus Schwarz (MV) vaccine strain on tumor cell lines in vitro. Live attenuated measles virus Schwarz vaccine strain was obtained from Aventis Pasteur, France. Live attenuated measles virus Schwarz strain was propagated on Vero, human Rhabdomyosarcoma (RD) and human GlioblastomaMultiform (GBM) cell lines which were supplied by Iraqi Center for Cancer and Medical Genetic Researches (ICCMGR). Results revealed that cell fusion occurred after $24 \mathrm{~h}$ of infection. The infected confluent monolayer appeared to be covered with syncytia with granulation and vaculation of cells after 72 to $120 \mathrm{~h}$. Moreover, the formation of large round empty plaque spaces was observed in infected cells. Results of oncolytic cytopathic effect showed that after $120 \mathrm{~h}$ of exposure alterations in morphology of Vero, RD and GBM cells. Cells were rounded, shrink, clustered cells and large empty space with cell debris as a result of cell lysis and death. Haemadsorption effect of MV was studied and result recorded that all cell lines infected with virus have the ability for haemadsorption human red blood cells after $72 \mathrm{~h}$ of infection. While uninfected cells gave negative results. Detection of MV H protein by monoclonal antibodies in infected cells of all cell lines by immunocytochemistry assay gave positive results (brown color) in cytoplasm of infected cells. Cell viability was measured after $72 \mathrm{~h}$ of infection by MTT assay. Results showed a significant cytotoxic effect for measles virus $(P \leq 0.05)$ on growth of RD and GBM cell lines at the first dilution and the second one after $72 \mathrm{~h}$ of infection. When the dilution increases, there was a significant decline in the inhibitory effect with a significant cytotoxic effect as compared with the control. Also, concentrated inoculums of measles virus showed a significant cytotoxic effect when compared with the control.
\end{abstract}

Keywords: measles virus, virotherapy, CPE of MV, MV H-protein.

\section{Introduction}

Cancer is one of the major health problems of our times (1). During the past two decades, the paradigm for cancer treatment has evolved from relatively nonspecific cytotoxic agents to selective, mechanism-based therapeutics. Cancer chemotherapies were initially identified through screens for compounds that killed rapidly dividing cells. These drugs remain the backbone of current treatment, but they are limited by a narrow therapeutic index, significant toxicities and frequently acquired resistance. More recently, an improved understanding of cancer pathogenesis has given rise to new treatment options, including targeted agents and cancer immunotherapy (2). Targeted approaches aim to inhibit molecular pathways that are crucial for tumor growth and maintenance (3). Oncolytic viruses are defined by their ability to specifically kill tumor cells, but to leave the normal tissues unharmed. Their most characteristic features, thus, are their target specificity and their cytolytic capacity. Ideally, they exhibit additional features including, but not limited to, a high reproductive capacity in vivo, the ability to recruit uninfected neighboring cells (syncytia formation), the ability to infect both dividing and non dividing cells, a high stability in vivo, the inability of chromosomal integration, the lack of disease induction, and the general absence of preexisting antibodies to the virus in the host population (4).

The use of replicating viruses for cancer therapy is attracting increasing interest. Numerous viruses are now being considered as potential cancer therapeutics, including the vaccine strain of measles virus (MV). MV is 
an envelope and negative, nonsegmented, single-strand RNA virus belonging to the Morbillivirus genus of the Paramyxoviridae family (5). The attenuated strain of measles readily lyses transformed cells, whilst replication and lysis are limited in normal human cells. It has a number of features which make it highly suitable for further development as an oncolytic agent, among them stability and a long history of safety in human use. These features are being combined with its ready potential for genetic manipulations to generate recombinant $\mathrm{MVs}$ with desirable therapeutic attributes (6). Peng et al. reported that a growing interest in oncovirotherapy using a number of replication-competent (oncolytic) viruses like MV for cancer therapy has emerged (7). Previous studies proved that different MV strains demonstrated potent oncolytic efficacy with minor or none side effects against multiple primary and established cancer cell lines and several preclinical animal tumor models including both solid tumors and hematologic malignancies such as ovarian cancer. Zhang et al. showed that a large variety of oncolytic viruses have been engineered, among the many oncolytic virus systems, the attenuated Edmonston vaccine strain of the measles virus (MV-Edm) has proven safe and effective (8).

To investigate the oncolytic activity of live attenuated measles virus strain, this study was aimed to:

- Propagation of live attenuated measles virus strain on Vero cell line.

- Studying the oncolytic cytopathic effect of live attenuated measles virus on Vero cell line.

- Characterazation of live attenuated measles virus by using some viral markers.

- Studying the cytotoxic effect of live attenuated measles virus on tumor cell lines in vitro.

\section{Methods Live attenuated virus vaccine against measles (Schwarz strain)}

Schwarz strain (Aventis Pasteur S.A., Lyon France) was obtained from a local health center in Baghdad-Ghazaliya.

\section{Cell culture}

Vero (African green monkey) cell line, RD cell line and human Glioblastoma-Multiform (GBM) cell line were supplied by Iraqi Center for Cancer and Medical Genetic Researches (ICCMGR). All cell lines were grown at $37^{\circ} \mathrm{C}$ in media recommended by ICCMGR. All media contained $200 \mathrm{U} / \mathrm{ml}$ penicillin and $100 \mathrm{U} / \mathrm{ml}$ streptomycin and were supplemented with $10 \%$ to $20 \%$ FCS (Cellgrew, USA) according to cell types.

\section{Measles virus propagation}

MV was propagated by infecting $1.5 \times 10^{6}$ Vero cells in T25 flasks in $3 \mathrm{ml}$ serum free media-MEM (US Biological, USA) at $37^{\circ} \mathrm{C}$ for $2 \mathrm{~h}$ then the medium was replaced with serum free media. The cells were incubated at $37^{\circ} \mathrm{C}$ for 3 to 5 days, and subsequently harvested in $1 \mathrm{ml}$ Opti-MEM. The viruses were then released by three cycles of freezing and thawing. The titers of viral stocks were determined by $50 \%$ end-point dilution assays (TCID50) on Vero cells in 96-well plates.

\section{Studying the cytopathic effect of measles virus and hem- adsorption test Cells seeding}

Cancer cells (RD and GBM) and Vero cells were dispersed with trypsin-EDTA (US Biological, USA), and suspended in growth media with $10 \% \mathrm{FCS}$, and 1-3 $\mathrm{ml}$ of cell suspension $\left(1 \times 10^{5}\right.$ cells/dish) was seeded in plastic tissue culture Petri dishes that contain sterile cover slips. Cell were incubated at $37^{\circ} \mathrm{C}$ for $24 \mathrm{~h}$ or until confluent monolayer was formed (9).

\section{Cells infection}

The procedure of infection with MV was carried out by removing the old media that contain serum and adding $1 \mathrm{ml}$ the virus solution (concentrated inoculums $=3.4^{*} 10^{5}$ ) for $2 \mathrm{~h}$ at room temperature with shaking to allow virus attachment and penetration. After that, cells were washed with PBS and serum free medium was added. Cells were incubated for three days or until cytopathic effect appeared (10). 


\section{Preparation of $1 \%$ human red blood cells solution}

Blood was collected from a healthy person in heparinized tube and washed three times with PBS by centrifugation at $1000 \mathrm{rpm}$ at $4^{\circ} \mathrm{C}$, the supernatant was discarded and $0.1 \mathrm{ml}$ of cell pellet was transferred to sterile graduated tube and the volume was completed to $10 \mathrm{ml}$ with PBS (11). Hem-adsorption of cell culture infected with Measles virus this procedure was carried out according to Haas et al. (12). As follows,

RD, GBM and Vero cell line infected with measles virus were washed three times with PBS after removing the old media. Aliquot of $1 \mathrm{ml}$ of $1 \%$ human red blood cells solution was added to cell sections. Cells were incubated with the RBCs solution for $30 \mathrm{~min}$ at $4^{\mathrm{O}} \mathrm{C}$, and then washed two times with PBS to remove non adsorbed RBCs. Finally adsorbed RBCs were fixed by adding $1 \mathrm{ml}$ of $4 \%$ formaldehyde and cells incubated for $30 \mathrm{~min}$ at $4^{\mathrm{O}} \mathrm{C}$. This experiment was done in the present of control groups of cancer cells that not infected with MV.

\section{Hematoxylin and Eosin staining}

As ICCMGR guidelines' cancer researches department, cell sections were immersed in hematoxylin solution for 5 minutes and washed in distilled water for three changes. Then cell sections were immersing in eosin solution for 2-3 minutes. Cell sections were dehydrated by immersing in $95 \%$ alcohol for 1. Then two changes were made in absolute alcohol for 2 minutes each. Clearing was made by adding xylene for 1 minute. Then absolute alcohol was added for two minutes to remove xylene. Finally cell sections were mounted with xylene based mounting medium (DPX).

\section{Detection of measles virus $H$ protein detection}

This was done by using immunoperoxidase kit for staining of cell lines infected with Measles virus. Measles H (6016) is monoclonal antibody generated against the Edmonston strain of Measles virus. The Principle of the test is that the primary antibody (monoclonal antibody) binds to the $\mathrm{H}$ - protein of measles virus, and the secondary antibody binds to determinants on the primary antibody. Then the avidin containing the horseradish peroxidase enzyme was allowed to bind to the biotin molecule attached to the secondary antibody. Staining procedure was done as Manufacturer Company (Santa Cruze Biotechnology, USA).

\section{Studying the oncolytic effect of MV on RD and GMB}

For cell viability assays, $7 * 10^{3}$ cells $/ 50 \mu \mathrm{l}$ were plated into 96-well plates and infected with the live-attenuated MV vaccine at two fold dilution. At the end of the incubation period, the virus was removed and the cells were maintained in serum free media. At 1, 2, 3, 4 and 5 day after infection, the cell viability was determined by MTT assay that measures the formation of insoluble formazan by mitochondria in viable cells. The reaction was subsequently discontinued by lysing the cells with $200 \mu$ of dimethyl sulfoxide (DMSO) for 15 min. Quantification measurements (optical density) were obtained at a wave length of $550 \mathrm{~nm}$ using spectrophotometric analysis (9).

\section{Statistical Analysis}

Paired sample T test was used within the SPSS version 20 program to analysis of data and studying the effect of MV on tumour cell lines at different incubation periods and dilutions. The difference was considered significant when the probability value $(\mathrm{P})$ was $\leq 0.05(24)$.

\section{Results and Discussion}

Cytopathic effect (CPE) of measles virus on RD and GBM cell line in vitro

The typical CPE of MV was the formation of mononuclear cell aggregates (syncytia) caused by cell-cell fusion (14). The measles virus showed a high ability for propagation and lysis of Vero cells. After $120 \mathrm{~h}$ of exposure alterations in morphological characteristics of Vero cells were cell rounded shrinkage, clustered cells and large empty space with cell debris as a result of cell lysis and death. While there were no morphological alterations in uninfected cells (Figs. (1 A and B)). MV showed the same effect on RD cells (Figs. (2 A and B)) and GBM cells (Figs. (3 A and $\mathrm{B})$ ). 


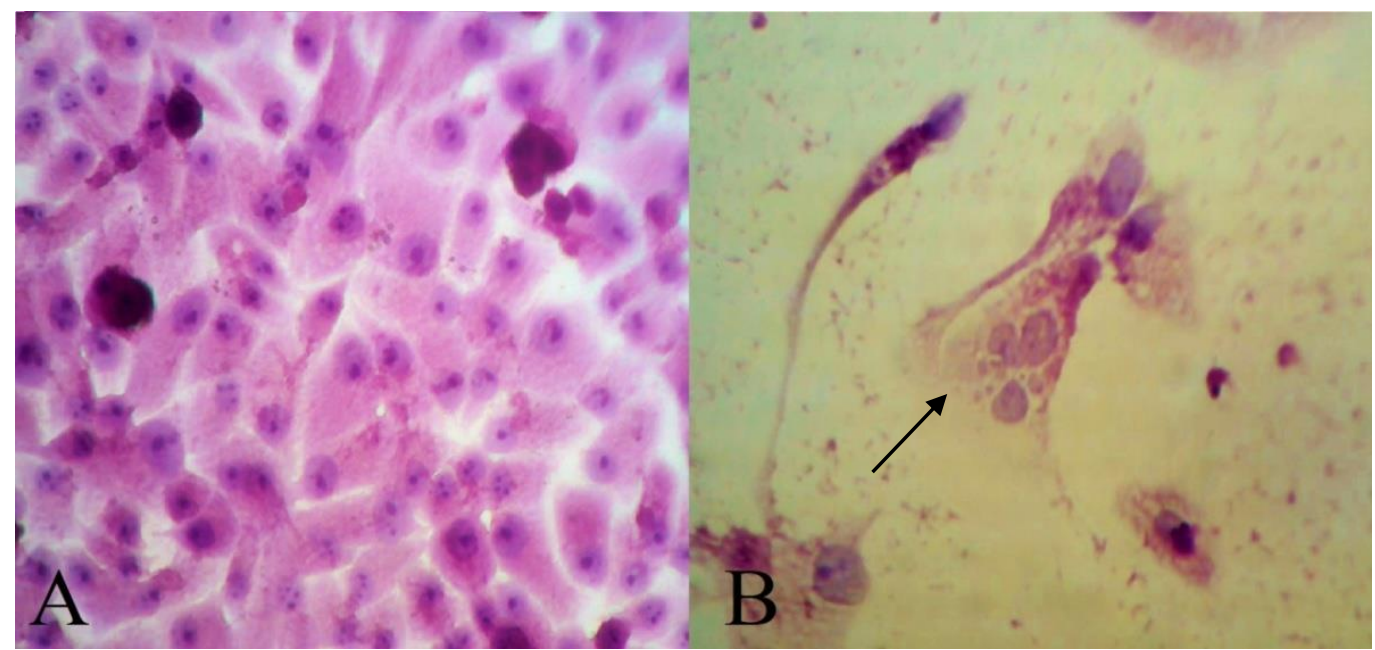

Fig.(1) CPE of measles virus on Vero cell line. A. Vero cells uninfected with virus. B. Black arrows showing syncytia and large empty space with cell debris after 120 h of MV infection $(H \& E) 40 X$.

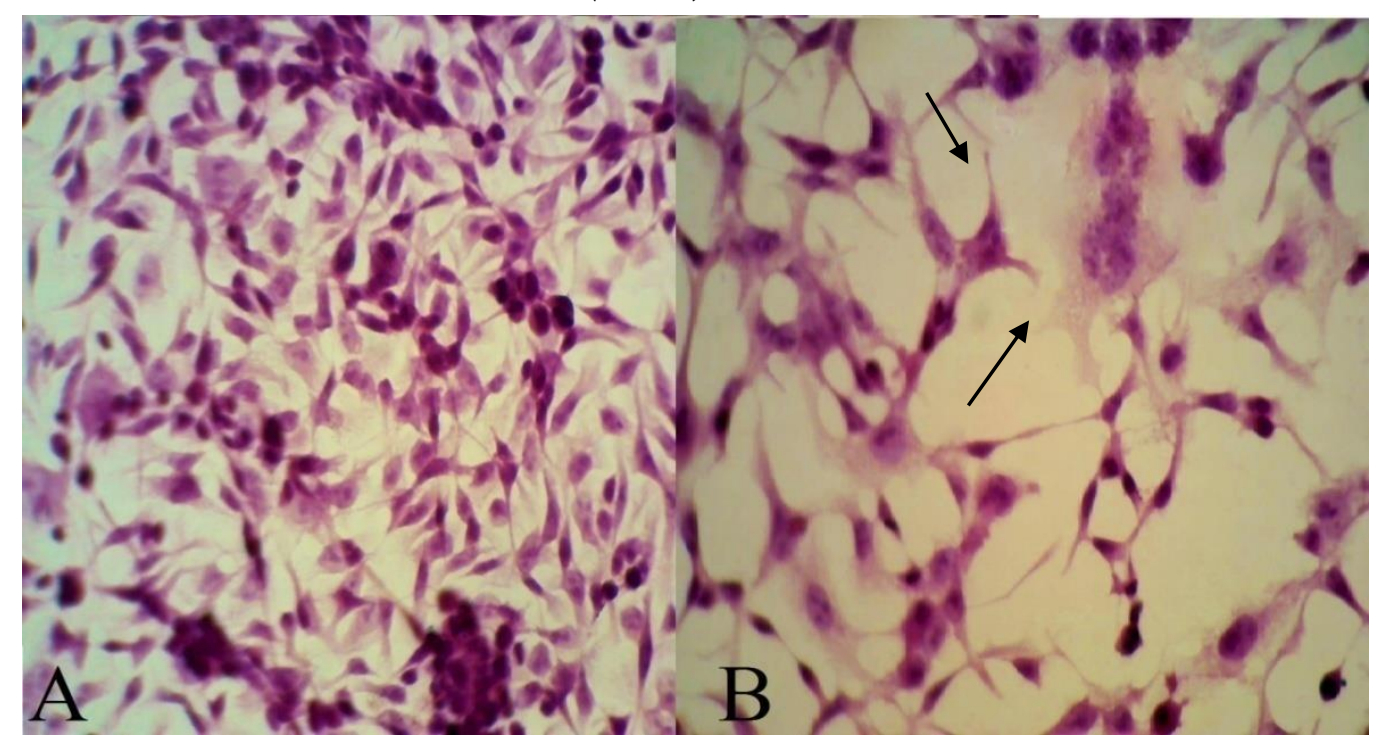

Fig.(2) CPE of measles virus on RD cell line. A. RD cells uninfected with virus. B. Black arrows showing syncytia and large empty space with cell debris after $120 \mathrm{~h}$ of $M V$ infection $(H \& E) 40 X$.

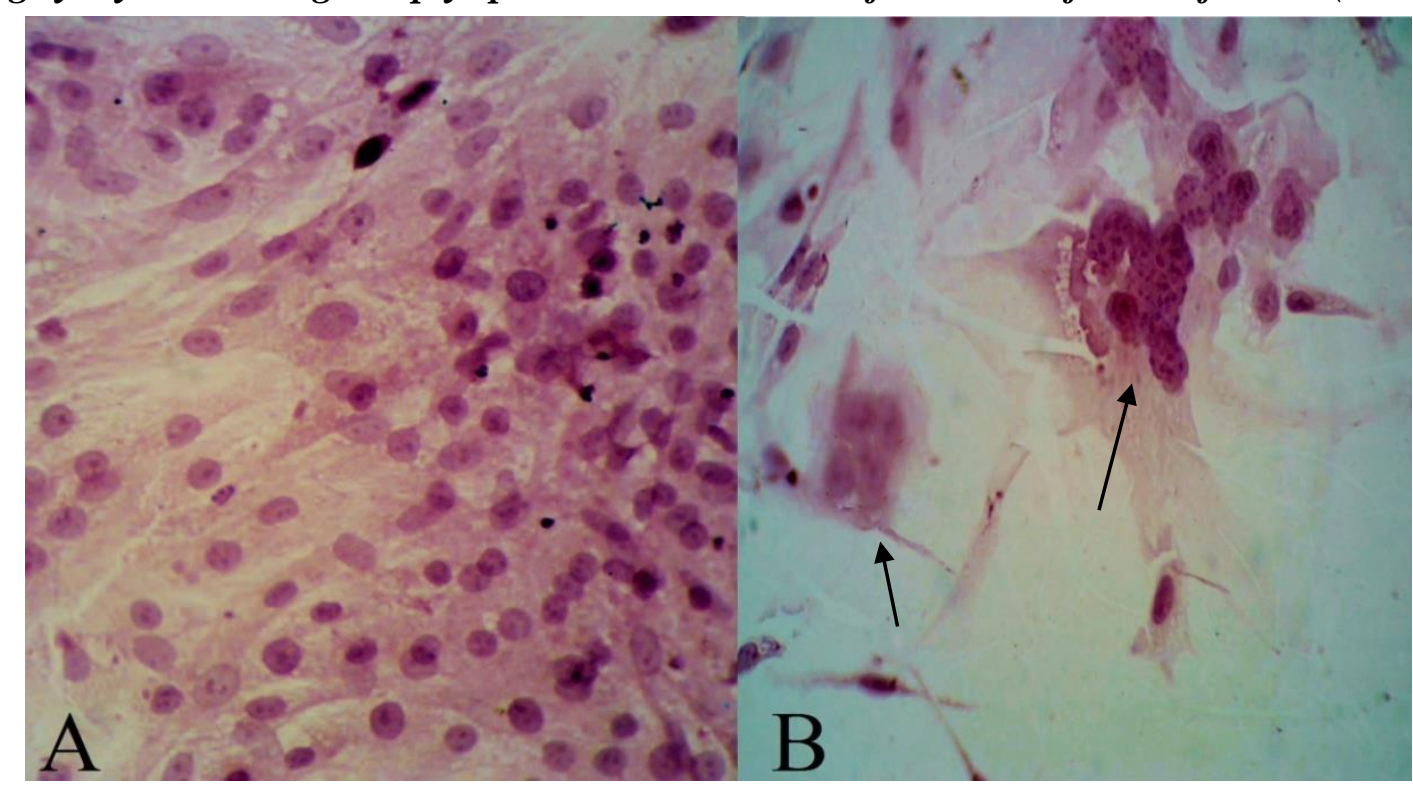

Fig.(3) CPE of measles virus on GBM cell line. A. GBM cells uninfected with virus. B. Black arrows showing syncytia and large empty space with cell debris after $120 \mathrm{~h}$ of MV infection (H\&E) 40X. 


\section{Haemadsorption effect of MV}

Results showed that all cell lines (Vero, $\mathrm{RD}$ and GBM) infected with virus have the ability to haemadsorp human red blood cells after $72 \mathrm{~h}$ of infection. While uninfected cells gave negative results for haemadsorption (Figs. (4 A and B)), (Figs. (5 A and B)) and (Figs. (6 A and B)).

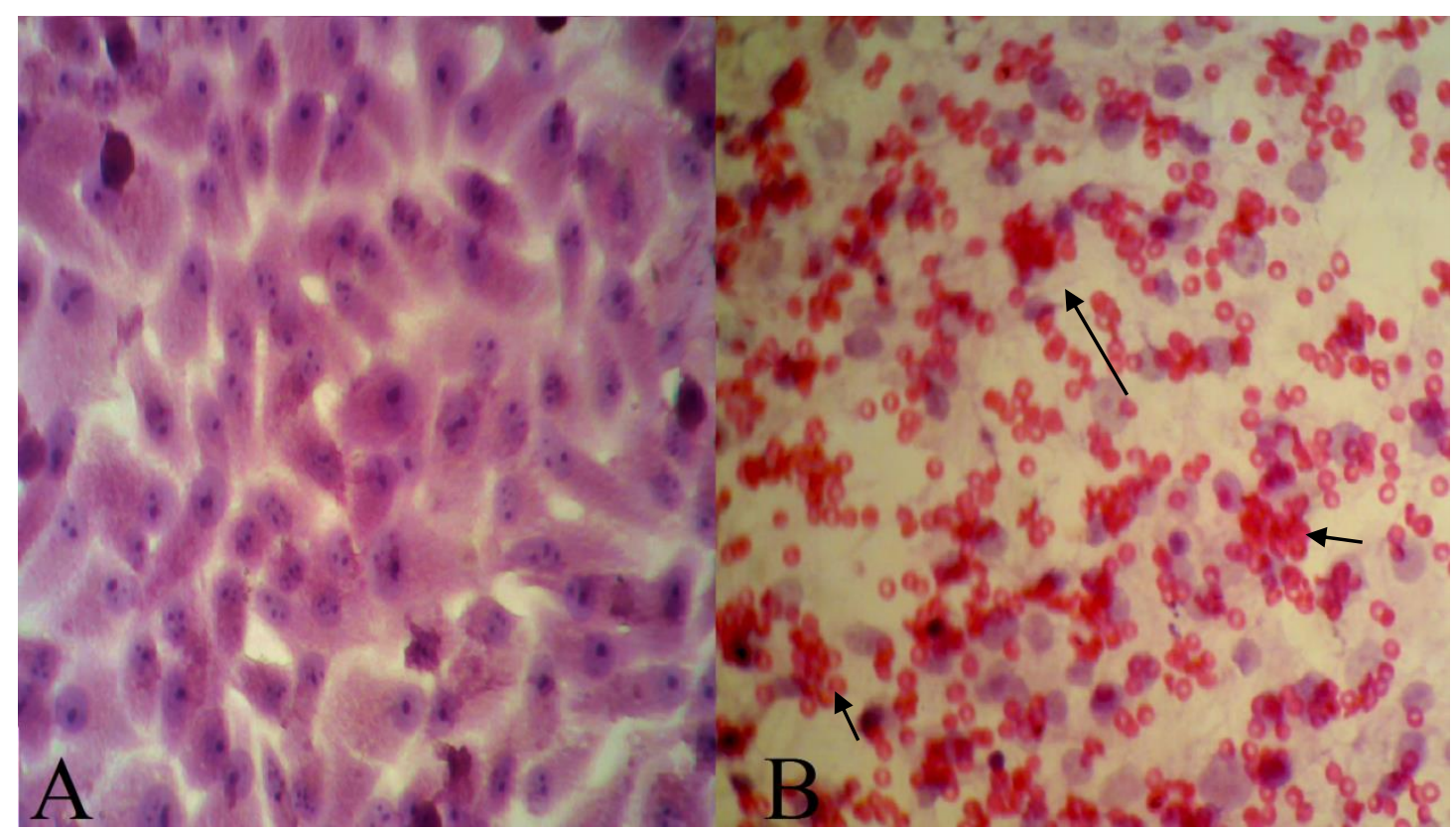

Fig.(4) Haemadsorption test of Vero cell line. A. Vero cells uninfected with measles virus and treated with human RBCs. B. Haemadsorption of human RBCs after $72 \mathrm{~h}$ of MV infection (Arrows) $(H \& E) 40 X$.

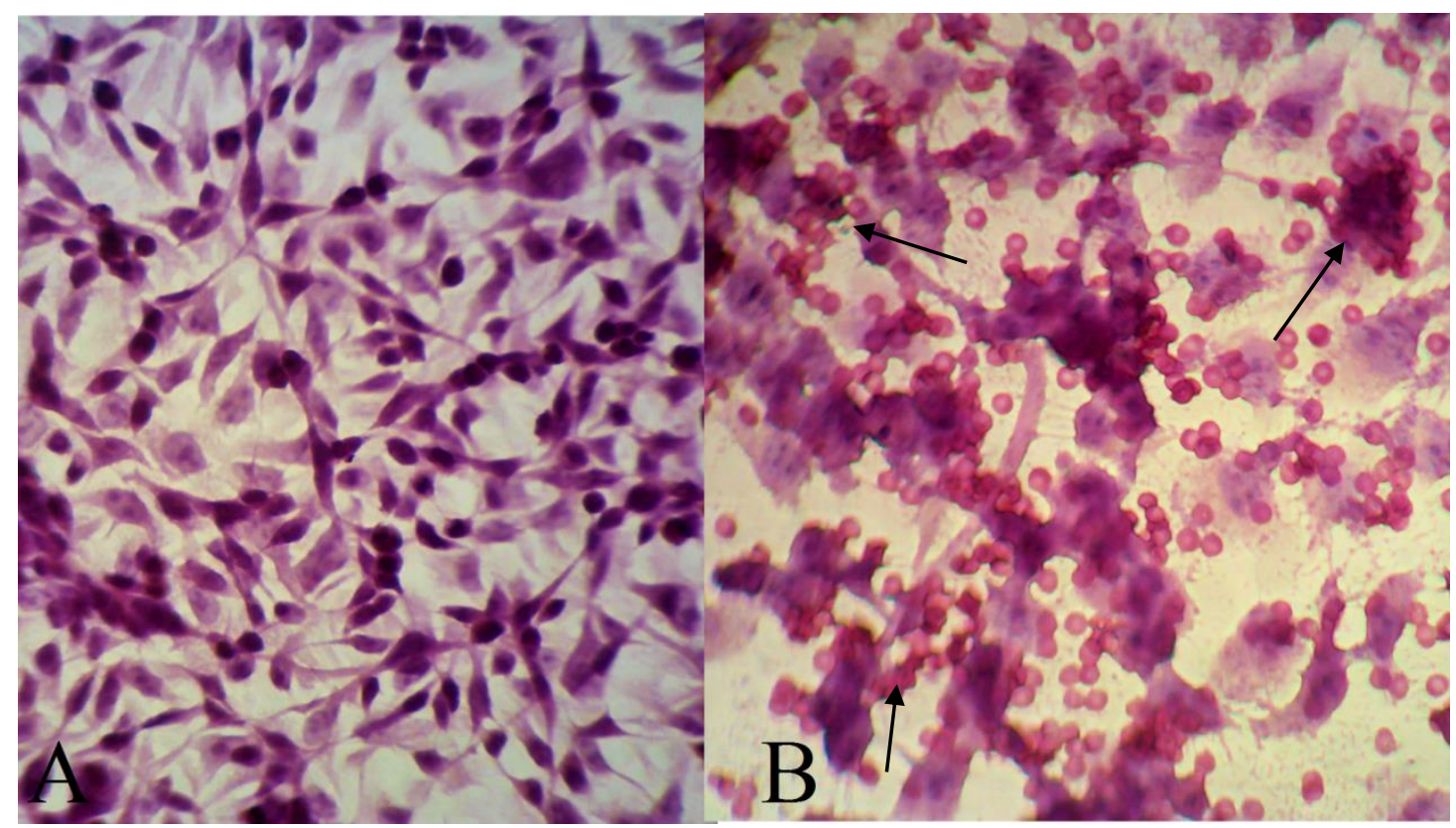

Fig.(5) Haemadsorption test of RD cell line. A. RD cells uninfected with virus. B. Haemadsorption of human RBCs after $72 \mathrm{~h}$ of infection (Arrows) (H\&E) 40X. 


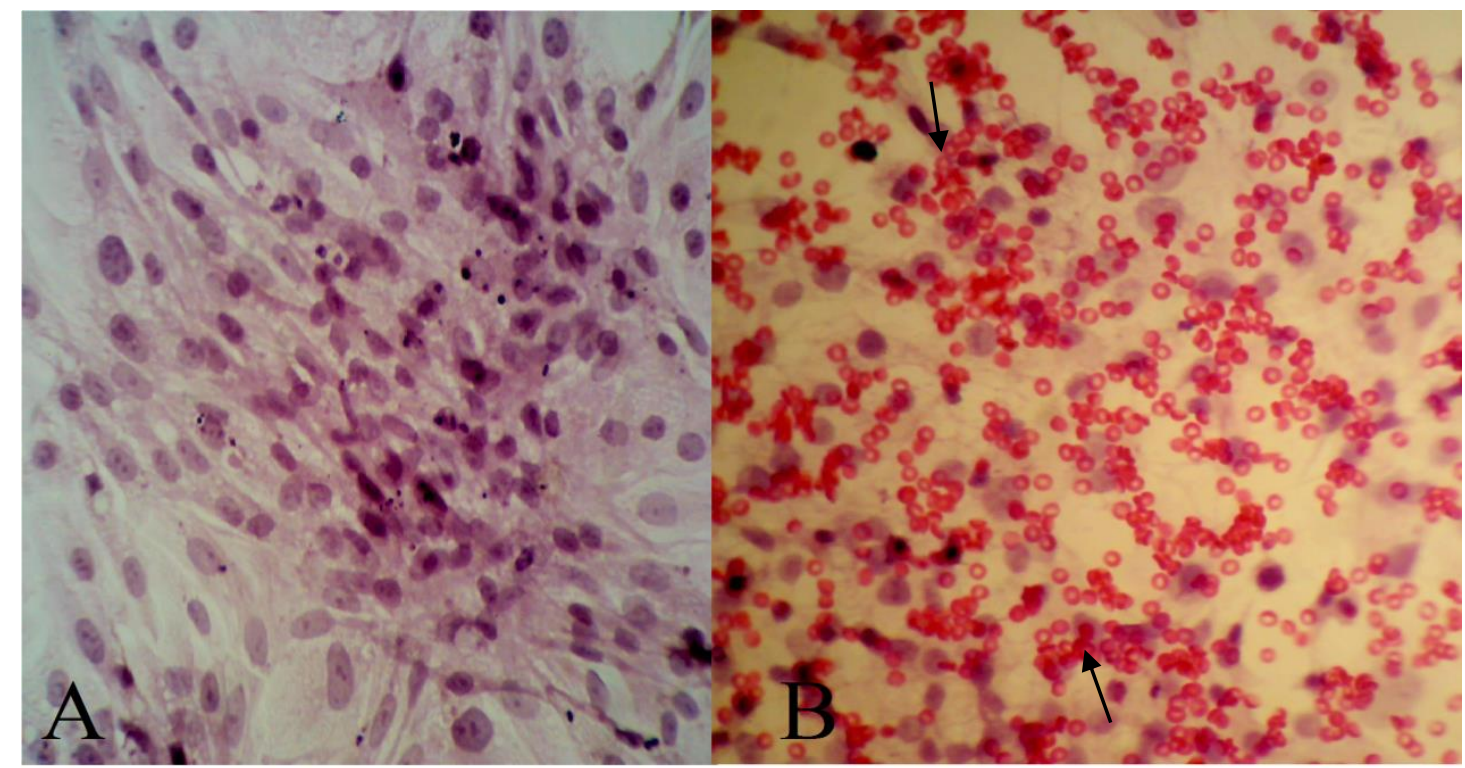

Fig.(6) Haemadsorption test of GBM cell line. A. GBM cells uninfected with virus. B. Haemadsorption of human RBCs after $72 \mathrm{~h}$ of infection (Arrows) (H\&E) 40X.

Detection of measles virus $\mathrm{H}$ - protein in infected cell lines

Monoclonal antibodies specific for $\mathrm{H}$ protein of measles virus in Vero, RD and GBM cell lines after $72 \mathrm{~h}$ and $120 \mathrm{~h}$ of virus infection showed that $\mathrm{H}$ protein was found in cytoplasm of infected cells as it stained brown color. While uninfected cells cytoplasm were negative stained. Nuclei of infected and uninfected gave blue color (Figs. (7 A, B, $\mathrm{C}$ and $\mathrm{D})$ ), (Figs. (8 A, B, C and D)) and (Figs. (9 A, B, C and D)).
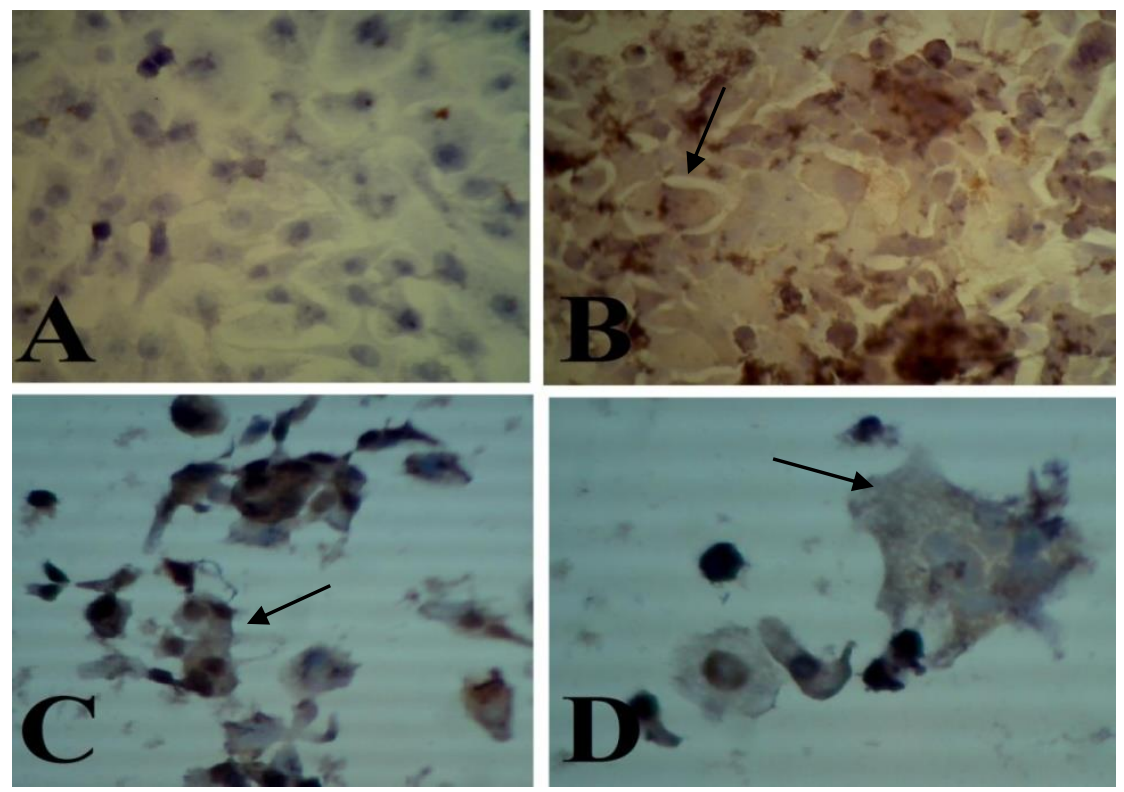

Fig.(7) Detection of MV H protein in Vero cell line. A. Cytoplasm of uninfected Vero cells showing no color with blue nuclei 40X. B. Cytoplasm of Vero infected with MV showing brown color and blue nuclei after $72 \mathrm{~h}$ of infection 40X. C. Cytoplasm of Vero cells showing brown color (arrow), blue nuclei, and dead cells with black color after $120 \mathrm{~h}$ of infection 40X.

D. Vero infected with MV for $120 \mathrm{~h}$ cells cytoplasm stains brown, nucleus stained blue 100X. 

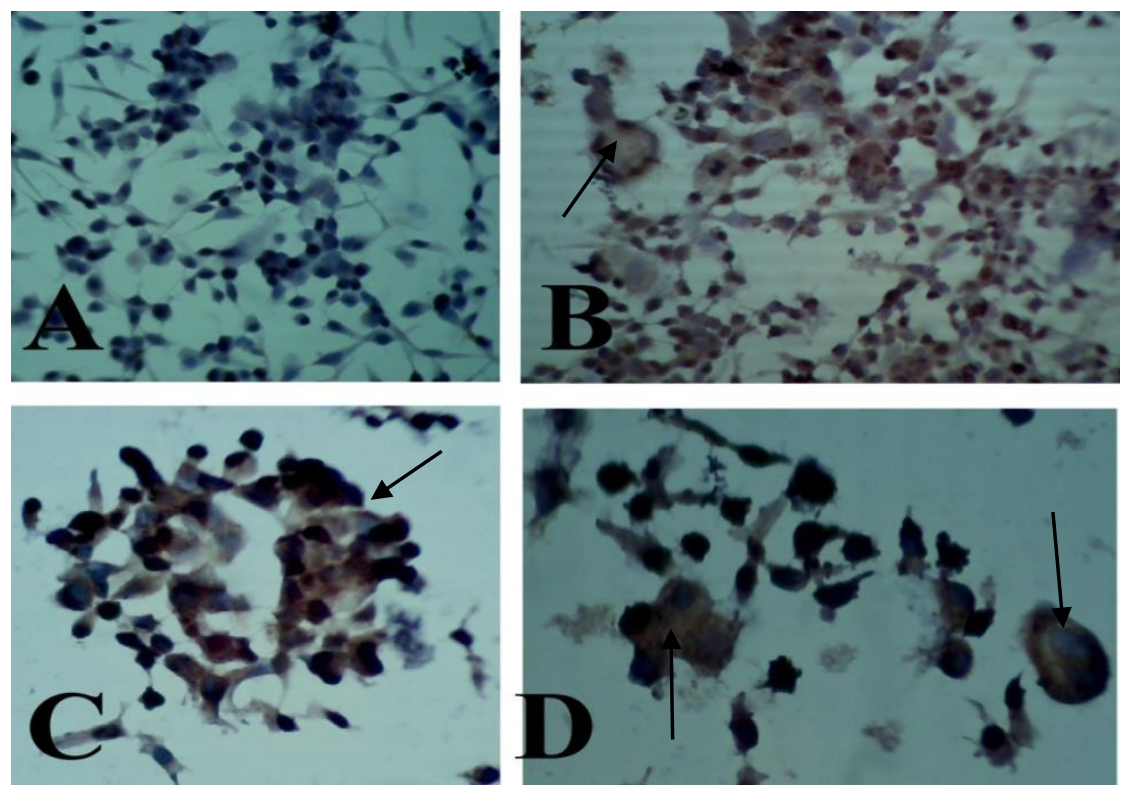

Fig.(8) Detection of MV H protein in RD cell line. A. Cytoplasm of uninfected RD cells showing no color with blue nuclei $40 X$. B. Cytoplasm of RD infected with MV showing brown color and blue nuclei after $72 \mathrm{~h}$ of infection 40X. C. Cytoplasm of RD cells showing brown color (arrow), blue nuclei, and dead cells with black color after 120 h of infection 40X. D. Cytoplasm of RD cells showing brown color (arrow), blue nuclei and dead cells with black color after $120 \mathrm{~h}$ of infection 100X.
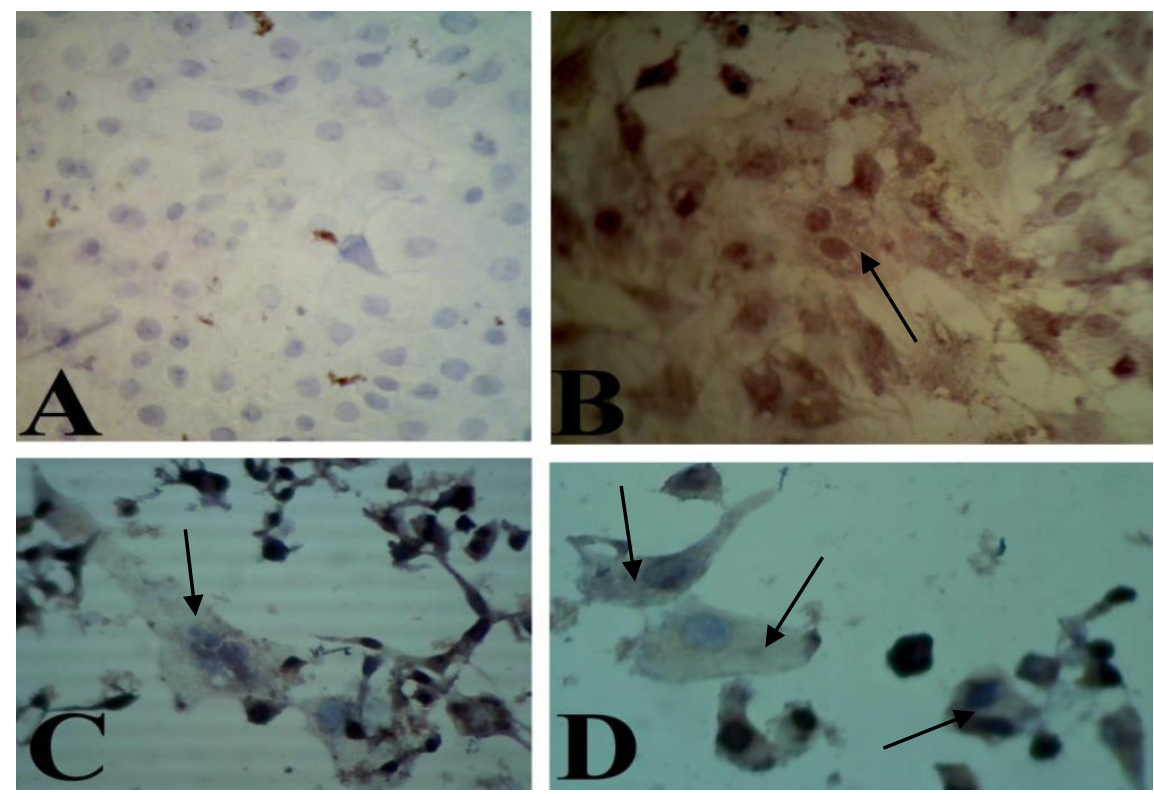

Fig.(9) Detection of MV H protein in GBM cell line. A. Cytoplasm of uninfected GBM cells showing no color with blue nuclei 40X. B. Cytoplasm of GBM infected with MV showing brown color and blue nuclei after 72 h of infection 40X. C. Cytoplasm of GBM cells showing brown color (arrow), blue nuclei, and dead cells with black color after $120 \mathrm{~h}$ of infection 40X.

D.Cytoplasm of GBM cells showing brown color, blue nuclei and dead cells with black color after $120 \mathrm{~h}$ of infection $100 \mathrm{X}$.

Cytotoxic effect of measles virus on RD and GBM

Results in Table (1) showed a significant cytotoxic effect for measles virus $(P \leq 0.05)$ on growth of RD cell line at the first dilution and the second one with growth inhibitory (GI) percentage were (56.778 and 60.439) \% respectively after $72 \mathrm{~h}$ of infection. When the dilution increase, there was a significant decline in the inhibitory effect with a significant cytotoxic effect when compared with the control with growth inhibitory percentage were $(38.616,31.039$ and 19.801) \% respectively. Also concentrated 
inoculums of measles virus showed a significant cytotoxic effect when compared with the control with GI percentage was $41.298 \%$, as shown in Table (1).

\section{Table (1)}

Cytotoxic effect of concentrated and diluted inoculum of measles virus on RD cell line after 72 h of infection.

\begin{tabular}{|c|c|c|}
\hline Dilution & $\begin{array}{l}\text { O.D. mean } \pm \\
\text { S.E.* }\end{array}$ & GI\% \\
\hline Control & $1.103 \pm 0.007 \mathrm{~A}$ & --- \\
\hline $\begin{array}{l}\text { Concentrated } \\
\text { inoculums } \\
\text { (TCID50/ml } \\
\left.=3.4^{*} 10^{5}\right)\end{array}$ & $0.761 \pm 0.004 \mathrm{~B}$ & 41.298 \\
\hline $\begin{array}{c}\text { Dilution1 (TCID50/ml } \\
\left.=1.7 * 10^{5}\right)\end{array}$ & $0.591 \pm 0.005 \mathrm{C}$ & 56.778 \\
\hline $\begin{array}{c}\text { Dilution 2(TCID50/ml } \\
\left.=8.5^{*} 10^{4}\right)\end{array}$ & $0.550 \pm 0.005 \mathrm{D}$ & 60.439 \\
\hline $\begin{array}{l}\text { Dilution3 (TCID50/ml } \\
\left.=4.25^{*} 10^{3}\right)\end{array}$ & $0.676 \pm 0.006 \mathrm{E}$ & 49.074 \\
\hline $\begin{array}{l}\text { Dilution4(TCID50/ml } \\
\left.=2.125 * 10^{2}\right)\end{array}$ & $0.791 \pm 0.003 \mathrm{~F}$ & 38.616 \\
\hline $\begin{array}{c}\text { Dilution5 (TCID50/ml } \\
=1.06 * 10)\end{array}$ & $0.875 \pm 0.004 \mathrm{G}$ & 31.039 \\
\hline $\begin{array}{c}\text { Dilution } 6 \\
(\mathrm{TCID} 50 / \mathrm{ml}=5.312)\end{array}$ & $0.999 \pm 0.007 \mathrm{H}$ & 19.801 \\
\hline
\end{tabular}

* different letters $=$ significant differences $(P \leq 0.05)$ between means of treatments and control.

The measles virus had a significant effect on GBM cells after $72 \mathrm{~h}$ of exposure when compared with the control at the dilutions 1, 2 and 3 with GI of (46.047, 73.183 and 58.012) \% respectively. A significant decrease in cytotoxic inhibition rate was recorded when the dilution increased with a significant cytotoxic effect at the dilutions (4, 5 and 6) with GI were $(27.350,19.658$ and 14.529) \% respectively. A concentrated inoculum of measles virus showed a significant cytotoxic effect when compared with the control with growth inhibition percentage was $46.047 \%$, as shown in Table (2).
Table (2)

Cytotoxic effect of concentrated and diluted inoculum of measles virus on GBM cell line after $72 \mathrm{~h}$ of infection.

\begin{tabular}{|c|c|c|}
\hline Dilution & $\begin{array}{l}\text { O.D. mean } \pm \\
\text { S.E.* }\end{array}$ & GI\% \\
\hline Control & $\begin{array}{c}0.936 \pm 0.003 \\
\mathrm{~A} \\
\end{array}$ & ---- \\
\hline $\begin{array}{l}\text { Concentrated } \\
\text { inoculums } \\
(\text { TCID50/ml } \\
\left.=3.4^{*} 10^{5}\right)\end{array}$ & $\begin{array}{c}0.505 \pm 0.003 \\
\mathrm{~B}\end{array}$ & 46.047 \\
\hline $\begin{array}{c}\text { Dilution1 } \\
(\text { TCID50/ml } \\
\left.=1.7 * 10^{5}\right) \\
\end{array}$ & $\begin{array}{c}0.302 \pm 0.001 \\
\mathrm{C}\end{array}$ & 67.735 \\
\hline $\begin{array}{c}\text { Dilution } \\
\text { 2(TCID50/ml } \\
\left.=8.5^{*} 10^{4}\right) \\
\end{array}$ & $\begin{array}{c}0.251 \pm 0.001 \\
\mathrm{D}\end{array}$ & 73.183 \\
\hline $\begin{array}{l}\text { Dilution3 } \\
(\text { TCID50/ml } \\
\left.=4.25^{*} 10^{3}\right)\end{array}$ & $\begin{array}{c}0.393 \pm 0.003 \\
\mathrm{E}\end{array}$ & 58.012 \\
\hline $\begin{array}{l}\text { Dilution4(TCID50/ml } \\
\left.=2.125^{*} 10^{2}\right)\end{array}$ & $\begin{array}{c}0.680 \pm 0.000 \\
\mathrm{~F} \\
\end{array}$ & 27.350 \\
\hline $\begin{array}{l}\text { Dilution5 } \\
(\mathrm{TCID} 50 / \mathrm{ml} \\
=1.06 * 10) \\
\end{array}$ & $\begin{array}{c}0.752 \pm 0.001 \\
G\end{array}$ & 19.658 \\
\hline $\begin{array}{c}\text { Dilution } 6 \\
(\text { TCID50/ml =5.312) } \\
\end{array}$ & $\begin{array}{c}0.800 \pm 0.001 \\
\mathrm{H} \\
\end{array}$ & 14.529 \\
\hline
\end{tabular}

* different letters $=$ significant differences $(P \leq 0.05)$ between means of treatments and control.

\section{Discussion}

Results of virus propagation showed that the live attenuated measles virus vaccine successfully cultivated and has been passed on African green monkey kidney cells (Vero cell line), RD cells and Iraqi cells GBM. Vero cells are susceptible to infection by measles virus (15). Known that MV enter through the natural measles receptors CD46 and spread by cellcell fusion, causing giant syncytia formation and killing the tumor cells (16). Results of this study showed that MV Schwarz strain efficiently killed tumor cells, and causing obvious cytopathic effect on infected cell lines after 72 to $120 \mathrm{~h}$ after infection. The cytopathic effect of $\mathrm{MV}$ is suggested to beginning after the viral hemagglutinin $(\mathrm{H})$ protein interacts with its receptor (CD46) on target cell. This interaction triggers conformational changes in the viral fusion $(F)$ protein that leads to fusion of the viral and cell 
plasma membranes, allowing the viral nucleoprotein complex to enter into the cell. The $\mathrm{H}$ protein interacts with $\mathrm{CD} 46$ on neighboring cells and can trigger membrane fusion between cells. As the expression of the viral $H$ and $F$ proteins increases, the probability that an infected cell fuses with a neighboring tumor cell increases. Once two cells fuse, there is an effective decrease in the concentration of viral proteins expressed on the cell surfaces and therefore there is a delay in spread of fusion until additional proteins are expressed on the surface. In time, this spread of cell-to-cell fusion leads to the formation of giant cell syncytia that normally die after a few days $(17 ; 18)$. Infected cells that have been incorporated into syncytia stop replicating and do not contribute to further growth of the tumor population. In addition, once infected cells die, they might release free virus particles that can infect surrounding cells (19).

Results of hemadsorption test showed that the cells infected with virus for $72 \mathrm{~h}$ have a positive result because measles virus contains surface glycoprotein known as haemagglutinin $(\mathrm{H})$, and these are capable of binding red blood cells. When virus replicates on cell culture, $\mathrm{H}$ molecules appear on the cell surface. If human red blood cells are added to the cell culture in which the virus is replicating, they will adhere to the cell sheet a phenomenon known as haemadsorption. The presence of haemadsorping viruses can therefore be detected several days before a cytopathic effect becomes apparent (20). While non infected cells have negative result to hemadsorption test.

In this study result of cytotoxicity test of live attenuated measles virus on human cancer cells (RD and GBM) after $72 \mathrm{~h}$ and $120 \mathrm{~h}$ showed that concentrated inoculums and higher dilutions of measles virus have low cytotoxic inhibition rate. While the low dilutions of measles virus caused higher cytotoxic inhibition rate. This result highlights the competition between viral replication, tumor cell growth and the death rate of infected tumor cells (21). Dingli et al (22) reported that the virus in high concentration cannot infect tumor cells because the surface receptors of tumor cells will be saturated with virus ligands. Moreover, Wodarz (23) reported that very low concentrations of virus which have infected cells are not available to infect additional cells, leading to a potential imbalance in the virotherapy.

\section{Conclusions}

Live attenuated measles virus Schwarz (MV) vaccine induces oncolytic cytopathic effect in Iraq tumor cell line GBM and in RD cell line. In addition, MV vaccine strain induces the formation of multinucleated giant cell (syncytia) in RD and GBM which may one causes of cell death. And has ability to insert its $\mathrm{H}$ protein to tumor cells which may lead to modified antigenic surface of tumor cell.

\section{References}

[1].Jemal, A.; Tiwari, R.; Murray, T.; "Cancer Statistics”; CA Cancer J Clin. 54, 8-29, 2004.

[2].Ahmedin, J.; Taylor, M.; Elizabeth, W.; Alicia, S.; "Cancer Statistics"; Cancer J Clin 55 (1):10-30, 2005.

[3]. Vanneman, M. and Dranoff, G.; "Combining immunotherapy and targeted therapies in cancer treatment"; Nat Rev Cancer 12, 237-251, 2012.

[4].Verheije, M. and Rottier, P.; "Retargeting of viruses to generate oncolytic agents"; Advances in virology. 2012.

[5].Moss, W.; Griffin, D.; "Global measles elimination"; Nat Rev Microbiol 4: 90008, 2006.

[6].Fielding, A.; "Measles as a potential oncolytic virus"; Rev. Med. Virol 15: 135142, 2005.

[7].Peng, K.; Hadac, E.; Russell, S.; "Pharmacokinetics of oncolytic measles virotherapy: eventual equilibrium between virus and tumor in an ovarian cancer xenograft model"; Cancer Gen. Ther. 13: 732-738, 2006.

[8].Zhang, S.; Wang, W.; Yuan, Z.; "Engineered measles virus Edmonston strain used as a novel oncolytic viral system against human hepatoblastoma"; BMC Cancer 12:427, 2012. 
[9].Freshney, R.; “Culture of Animal Cells: A Manual of Basic Technique and specialized application" (6th. ed); WileyLiss, A. and Wiley, J. (eds.). Inc. publication. New York, U.S.A. 2010.

[10]. Al-Shammari; "Newcastle disease Virus therapy for transplanted tumors in combination with chemotherapy"; Ph.D .Dissertation; Veterinary Medicine University of Baghdad. 2010.

[11]. Bell, D.; Roberts, N.; Madore, H.; Hall, C.; Simons, R.; "Hemadsorption focus assay for growth of influenza and parainfluenza viruses in human dermal fibroblasts (42112)"; Proc. Soc. Exp. Biol. Med. 179: 377-381, 1985.

[12]. Haas, C.; Ertel, C.; Gerhards, R.; Schirrmacher, V.; "Introduction of adhesive and co-stimulatory immune functions in to tumor cells by infection with Newcastle disease virus". Intern. J Oncology 13: 1105-1115, 1998.

[13]. Hand, A.; Sun, T.; Barber, D.; Hose, D.; MacNeil, S.; "Automated tracking of migrating cells in phase-contrast video microscopy sequences using image registration"; J microscopy 234(1):62-79, 2009.

[14]. Wild, T.; Malvoisin, E.; Buckland, R.; "Measles virus: Both the haemagglutinin and fusion glycoproteins are required for fusion"; J Gen Virol. 72(2):439-442, 1991.

[15]. Norrby, E.; Oxman, M.; "Measles Virus"; In: Fields BN, Knipe DM, et al, eds. Virology. New York, NY: Raven Press.1013-1044, 1990.

[16]. Yanagi, Y.; Takeda, M.; Ohno, S.; "Measles virus: cellular receptors, tropism and pathogenesis". J. Gen. Virol. 87, 276779, 2006.

[17]. Peng, K.; Ahmann, G.; Pham, L.; Greipp, P.; Cattaneo, R.; Russell, S.; "Systemic therapy of myeloma xenografts by an attenuated measles virus"; Blood. 98 (7), 2007.

[18]. Peng, K.; TenEyck, C.; Galanis, E.; Kalli, K.; Hartmann, L.; Russell, S.; "Intraperitoneal therapy of ovarian cancer using an engineered measles virus"; Cancer Res. 62 (16), 4656-4662, 2002.
[19]. Russell, S.; Bajzer, Z.; Carr, T.; Josic, K.; Dingli, D.; "Modeling of cancer virotherapy with recombinant measles viruses"; J. Theoretical Biology. 252:109122, 2008.

[20]. Koneman, E.; Allen, S.; Janda, W.; Schreckenberger, P.; Winn, W.; "Color Atlas and Text book of Diagnostic Microbiology"; 5th ed. Philadelphia: Lippincott Williams \& Wilkins; 1241, 1997.

[21]. Friedman, A.; Tian, J.; Fulci, G.; Chiocca, E.; Wang, J.; "Glioma virotherapy: effects of innate immune suppression and increased viral replication capacity"; Cancer Res. 66, 2314-2319, 2006.

[22]. Dingli, D.; Cascino, M.D.; Josic, K.; Russell, S.J.; Bajzer, Z.; "Mathematical modeling of cancer radiovirotherapy"; Math. Biosci. 199(1), 55-78, 2006.

[23]. Wodarz, D.; "Gene therapy for killing p53-negative cancer cells: use of replicating versus non replicating agents"; Hum. Gene Ther. 14 (2), 153-159, 2003.

[24]. IBM Corp. IBM SPSS Statistics for Windows, Version 20.0. Armonk, NY: IBM Corp. 2011.

الخلاصة

أجريت هذه الدراسة لتقييم تأثنر لقاح فيروس الحصبة

الحية المضعفة من سلالة اللقاح شفارتز على خطوط الخلايا السرطانية في المختبر • تم تكثير فيروس لقاح الحصبة شفارتز بعد الحصول عليها من افنتش باستورعلى الخط الخلوي (Vero) والخط الخلوي السرطاني للخلايا العضلية المخططة للإنسان (RD) والخط الخلوي السرطاني العراقي الاصل ورم أرومي دبقي- المتعددة الأشكال (GBM) بعد الحصول عليها من المركز العراقي لسرطان و الأبحاث الجينية الطبية (ICCMGR). اظهرث النتائج اندماج الخلية بعد \& ساعة من الاصابة لتكون مغطاة بخلايا عملاقة تدعى syncytia مع التحبيب و التعدد الفجواتي للخلية بعد

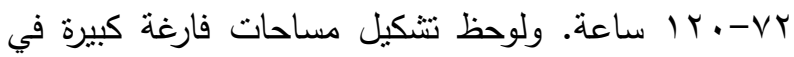
الخلايا المصابة. لتقييم التأثير الخلوي الممرض للفايروس في الخلايا السرطانية ، كانت الخلايا كلآ من RD ، RD و و 


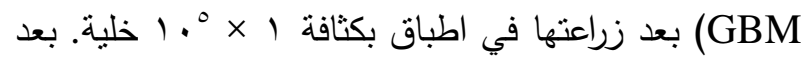

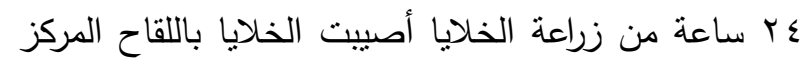

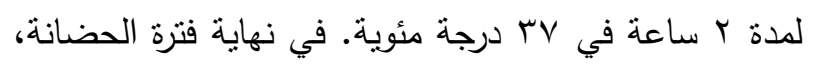

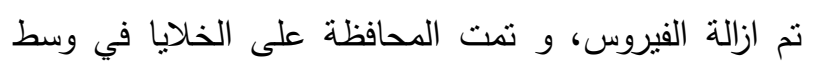
زرعي وحضنت لحين ظهور التأثنير الخلوي الممرض. أظهرت النتائج أن بعد 120 ساعة من التعريض للفيروس فئن تغيرات في الثكل لكل من Vero و و RD و

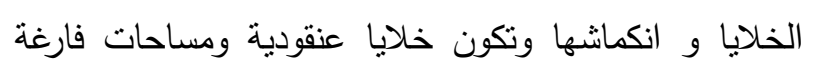

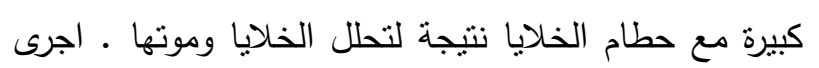

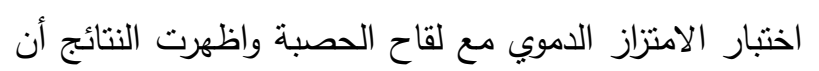
جميع خطوط الخلية المصابة بفيروس الحصبة لديها القدرة

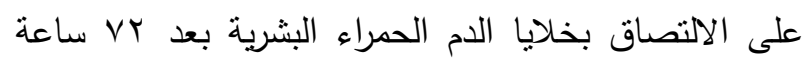
من الاصابة. بينما أعطت الخلايا غير المصابة نتائج سلبية. الكثف عن بروتين (H) بواسطة الأجسام المضادة وحيدة

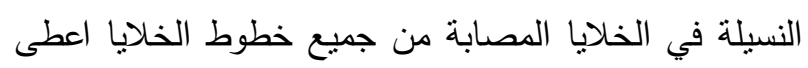
نتائج إيجابية (اللون البني) في سيتوبلازم الخلايا المصابة. أجري تقييم للتأثنر السمي الخلوي للقاح الحصبة MV وقيست حيوية الخلية بعد VBM RD

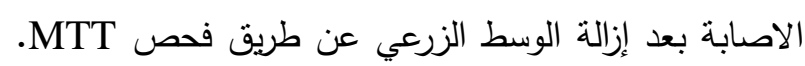

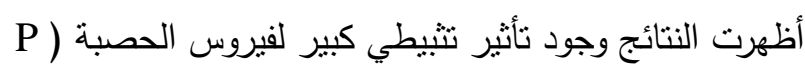

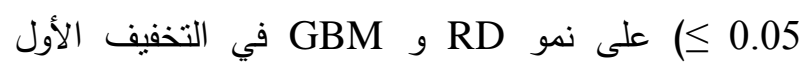
والثاني بعد VY ساعة من الاصابة. كما لوحظ انخفاضآ كبيرآ في التأثثر المثبط للفيروس مع وجود نأثير سمي للخلايا كبير بالمقارنة مع السيطرة. فضلآ عن ذلك أظهر لقاح فيروس

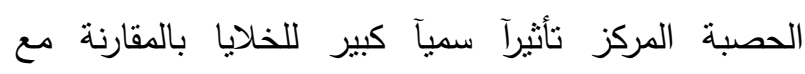
السيطرة. 